UDC 616-02:614.78

DOI: $10.21668 /$ health.risk/2018.1.01.eng

\title{
REGULATORY-LEGAL AND METHODICAL ASPECTS OF SOCIAL-HYGIENIC MONITORING AND RISK-ORIENTED SURVEILLANCE MODEL INTEGRATION
}

\author{
A.Yu. Popova ${ }^{1}$, N.V. Zaitseva ${ }^{2}$, I.V. May ${ }^{2}$, D.A. Kiryanov ${ }^{2}$ \\ ${ }^{1}$ Federal Service for Surveillance on Consumer Rights Protection and Human Wellbeing, 18 Vadkovskiy lane, \\ build 5 and 7, Moscow, 127994, Russian Federation \\ ${ }^{2}$ Federal Scientific Center for Medical and Preventive Health Risk Management Technologies, 82 Monastyrskaya \\ Str., Perm, 614045, Russian Federation
}

The authors stress in the paper that at a moment when a large-scale administrative reform of controlsurveillance activities in the Russian Federation took place there was an efficient tool greatly compatible with control and surveillance activities, a so called social-hygienic monitoring system. When control and surveillance activities and social and hygienic monitoring are brought together, it is a process when mutual integration of both systems takes place; results obtained in one of them give grounds for planning in another. Control and surveillance activities should give precise and targeted recommendations for the social social-hygienic monitoring system for those objects which are to be observed systematically. Both systems accumulate data on which obligatory requirement this or that surveillance object is likely to violate. The monitoring systems allows to make scientifically grounded choice on observation points and monitoring programs development taking all zones influenced by risk sources into account.

Measurement results are aimed at validated and precise determination of unacceptable health risk occurrence or threats to human life or health as well as an object causing such threats. But still each systems continues to solve each own tasks attributable only to it.

Both systems, social-hygienic monitoring and control and surveillance activates, are becoming dynamic. Monitoring points and observations programs are changing in accordance with surveillance authorities actions and economic entities reactions to such actions. Control and surveillance authorities get another tool which helps to further validate their efficiency over the previous time periods.

System management processes are cyclic and have time gaps between specific stages during a year; it causes substantial time expenses which are necessary to obtain optimal parameters. The overall management cycle for one system is equal to 4 years, and for combined systems, 8 years.

Key words: social-hygienic monitoring, control and surveillance activities, combination, risk-oriented model, management.

Surveillance and control activities are implemented in the sphere. These changes now being reformed in the Russian Federa- are to make overall administrative burden tion and risk-oriented approaches are being for businesses lower but in no way should

(C) Popova A.Yu., Zaitseva N.V., May I.V., Kiryanov D.A., 2018

Anna Yu. Popova - Doctor of Medicine, Professor, Head (e-mail: depart@gsen.ru; tel.: +7 (499) 458-95-63).

Nina V. Zaitseva - Member of the Russian Academy of Sciences, Doctor of Medical Sciences, Professor, Research Supervisor (e-mail: znv@,fcrisk.ru; tel.: +7 (342) 237-25-34).

Irina V. May - Doctor of Biological Sciences, Professor, Deputy Director for Scientific Work (e-mail: may@,fcrisk.ru; tel.: +7 (342) 236-32-64).

Dmitry A. Kiryanov - Candidate of Technical Sciences, Head of the Department of Mathematical Modeling of Systems and Processes (e-mail: kda@,fcrisk.ru; tel.: +7 (342) 237-18-04). 
they result in loss of the state control over the situation. It is especially true for these spheres under surveillance where the state protects such values as life and health of the country citizens.

Authorities which are responsible for sanitary surveillance in the RF were created almost 100 years ago and they have been improving procedures and forms of hygienic and epidemiologic assessments aimed at detecting hazards for citizens' health ever since [1]. So, they now possess a wide range of instruments for providing sanitary-epidemiologic welfare in the country as an addition to control and surveillance mechanisms which are now being administratively restructured. Socialhygienic monitoring (SHM) is one of such instruments (and we must say, the most efficient one) [1-3]. "Regulations on socialhygienic monitoring procedures"1, approved by the RF Governmental Order on February 2, 2006, No. 60 and being in force at the moment set forth the following basic SHM tasks:

- to perform hygienic assessment of the environment and population health;

- to reveal cause-and-effect relations between population health and impacts exerted by environmental factors basing on the systemic analysis and health risks assessment;

- to detect causes and conditions which made for occurrence and spread of infections and mass non-infectious diseases (intoxications);

- to work out propositions how to eliminate detected hazardous impacts exerted by environmental factors.
Social-hygienic monitoring was initially implemented to accumulate information which could help to reveal cause-and-effect relations between the RF population health and factors influencing it. It was also to provide informational support for managerial decisions at various levels of public administration. As a result, social and hygienic monitoring is now a complicated open system which for many years has been accumulating and processing heterogeneous data on environmental factors, social and economic parameters of people's life in the country regions, medical and demographic peculiarities of the society in general and specific population groups $[3,4]$.

Any complicated system which integrates data flow from various sources has its drawbacks; the same is the case with SHM, and these drawbacks are to be eliminated. However, there is no other state monitoring system in the RF which involves comprehensive interdepartmental interaction and collects such diverse data as SHM. The system has accumulated results of instrumental environmental quality measuring in all the RF subjects over the years of its functioning. In 2017 Rospotrebnadzor's authorities and offices acting within SHM frameworks took and analyzed more than 1.1 million atmospheric air samples; assessed drinking water quality taken from centralized water supply systems at more than 11,000 monitoring points; analyzed soils samples taken at more than 8,000 points located in settlements [5]. The federal information fund created due to such activities is practically inexhaustible from the analytical point of view and allows

\footnotetext{
${ }^{1}$ On approval of Regulations on social-hygienic monitoring procedures: The RF Governmental Order signed on February 2, 2006. No. 60. Available at: http://www.ohranatruda.ru/ot biblio/normativ/data_normativ/46/46812/ (20.01.2018).

${ }^{2}$ On making alterations into the Federal Law «On protection of juridical persons and sole proprietors when the state and municipal control (surveillance) procedures are performed: Federal Law passed on July 03, 2016 No, 277-FL». Available at: http://www.consultant.ru/document/cons doc LAW 200571/3d0cac60971a511280 cbba229d9b6329c07731f7/\#dst100049 (12.02.2018).
} 
to perform scientifically intense data processing to solve various tasks, including those set in the sphere of surveillance and control improvement $[6,7]$.

We should note that the system was created in such a way that its functional development was quite possible. When a new methodology of health risk assessment under exposure to hazardous environmental factors was introduced into the system, it has become the most significant progressive change in SHM since the moment it was created. Results obtained via health risk assessment enabled detection of regional and local priority factors, determination of zones where health risks were high, or, on the contrary, territories which were sanitary and epidemiologically safe $[8,9]$.

A new concept, "control activities performed without interaction with juridical persons or sole proprietors", was fixed in the Federal Law passed on July 03, 2016 N 277-FL ${ }^{2}$; this concept was fundamentally new, and it gave an additional impulse for the social and hygienic monitoring development. The clause 8.3 , added to the Law, states that "... examining and measuring parameters of environmental objects (atmospheric air, water, soils, and planetary interior) within performance of the state ... social and hygienic monitoring according to procedures fixed in the RF legislation" belong, among others, to such control activities the performance of which does not require any interaction between a public authority and juridical persons or sole proprietors.

So, the legislation fixes a direct correlation between two most important Rospotrebnadzor's functions, performance of control and surveillance activities and social and hygienic monitoring. This combination of two basic functions is quite harmonious and well justified. As SHM most significant task, from its very beginning, was to examine correlations within "environment - health" system, it has always focused on objects which could cause hazards and risks for human health. A new model of surveillance and control activities, in its turn, is aimed at stricter surveillance at objects which cause the greatest risks for protected values, first of all, people's life and health [10-13]. Here control and surveillance involve prevention, detection, and elimination of sanitary legislation violations, including those which cause environmental contamination [14].

Given such conditions, the combination of control and surveillance activities and social and hygienic monitoring is a process when two systems become mutually integrated, and the results obtained in one of them, give grounds for planning in another. But still, each system continues to solve independent tasks which are only its responsibility (Figure 1).

But at the same time, mutual penetration of the systems requires new tasks being set and solved in each of them. Control and surveillance activities are to give clear and targeted recommendations for social and hygienic monitoring concerning objects which require systemic observations in zones influenced by them. If we wish to optimize SHM exactly as per control and surveillance activities results, we are to understand, which obligatory requirements are most likely to be violated by this or that object under surveillance. Social and hygienic monitoring has to give scientific grounds for the selection of monitoring points and programs which are to be closely connected with a zone influenced by an object which causes health risks. Consequently, measurement results are to validate occurrence and level of intolerable health risks or threat of damage to people's life and health as well as to give clear evidence on an object which causes such risks or threats. 


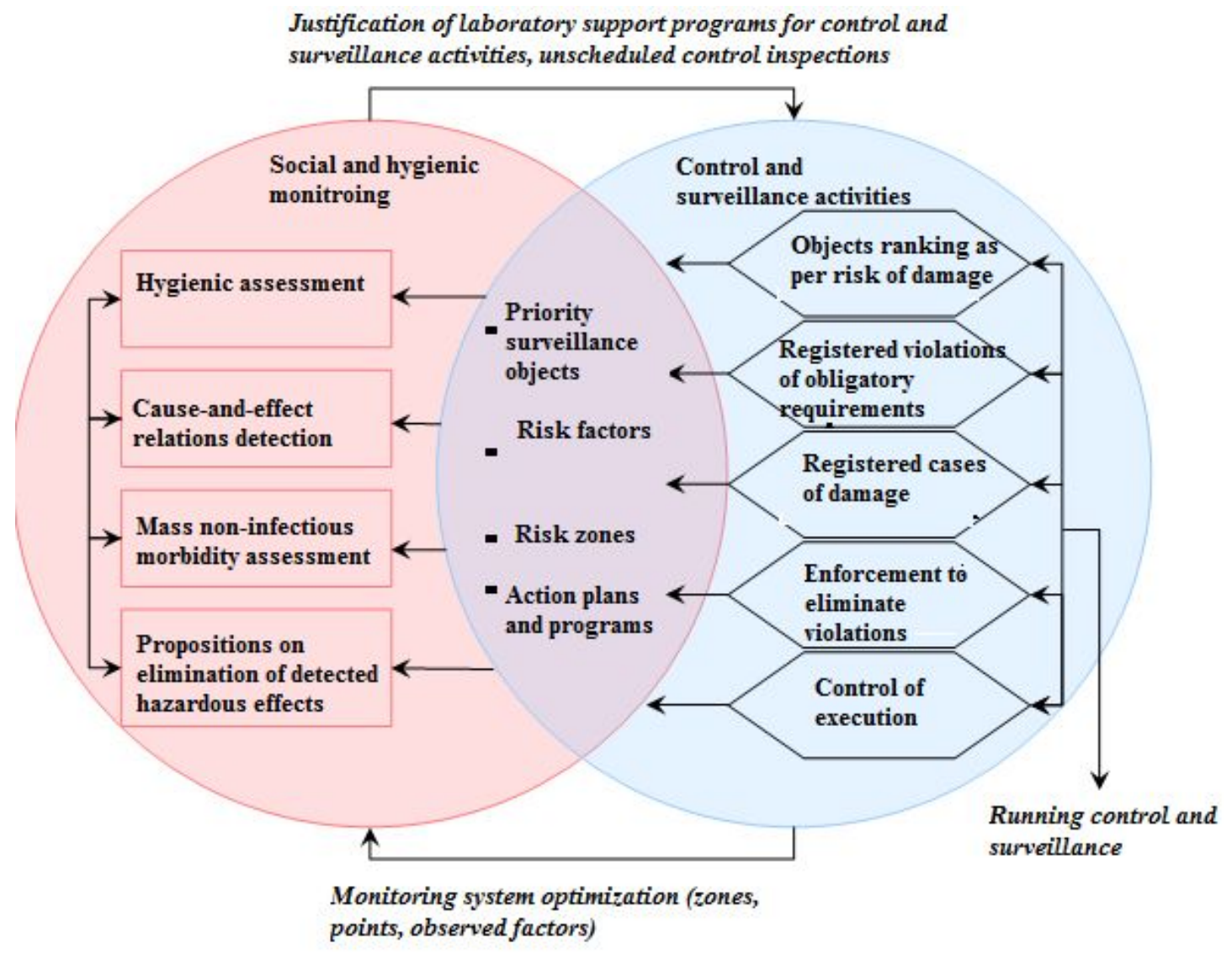

Figure1. The general scheme for combination of social and hygienic monitoring and control and surveillance activities by Rospotrebnadzor

The results of two systems being combined is their mutual enrichment:

- instrumental examinations programs are created allowing for objects being ranked as per potential health risks and they can be based on more informative data;

- research results obtained via correct and targeted programs can, in their turn, give informational grounds for control activities performed without any interaction with juridical persons or sole proprietors.

Such mutual enrichment makes both systems, social and hygienic monitoring and control and surveillance activities, become dynamic and cyclic. Monitoring points and programs are changed relevantly to activities performed by controlling authorities and to response measures taken in relation to actions by economic entities.
Control and surveillance authorities get an instrument which additionally confirms efficiency of their own activities performed in previous time periods. They can also monitor whether their responses to economic entities' actions were efficient or not.

There is a dynamic planning concept created in management theory; this concept is known as Deming cycle. It means that quality of all the results obtained in any activities is constantly regulated via consequent steps which are usually denominated as follows: Plan - Do - Check - Act (PDCA). Deming cycle, when it is applied in Rospoternadzor functioning, is in its essence a process of consequent increase in the efficiency of the performed activities (their optimization) due to surveillance activities being planned and organized allowing for social and hygienic monitoring re- 
sults, and monitoring, in its turn, being planned and organized allowing for the results of inspections conducted at industrial objects.

Separate stages are divided into different time periods, and it is a peculiarity of Rospotrebnadzor surveillance and control activities optimization. In other words, if we perform planning during a time period $\mathrm{t}$, then surveillance is conducted during $\mathrm{t}+1$, results are checked during $\mathrm{t}+2$, they are analyzed and activities are optimized during $\mathrm{t}+3$. The process is a helix-like one, and if we allow for specific features of surveillance and control activities planning, organization, and performance within Rospotrebnadzor system, we can state that a time interval between the steps (time lag) amounts to 1 year.

An increase in control and surveillance activities efficiency is closely related to the same process in social and hygienic monitoring.

Although optimization processes for control and surveillance activities and social and hygienic monitoring are quite similar, the latter has a peculiarity as its cycle has a reverse direction. But at the same time the cycles have common elements and two helix-like processes interact. Figure 2 shows a three-dimensional image of interaction between the cycles where blue arrows show control and surveillance activities management, and red ones, SHM system management.

Cyclic processes of the systems management with time lags between separate steps being equal to 1 year leads to substantial time costs which are necessary for obtaining optimal parameters. As we can see from the schemes given in Figure 2, the full managerial cycle for each separate system is equal to 3-4 years, and for their combination, to 6-8 years.

We should also note that although time lags lead to greater time required for finding optimal solutions, the management process is continuous. Moreover, as socialeconomic, sanitary-epidemiological, and medical and demographic situation is constantly changing, any optimal solution can only be temporary. Consequently, the basic managerial task in the combined "control and surveillance activities - social and hygienic monitoring" system is to form such managerial decisions which are as efficient as possible in terms of its improvement.

Implementation of theoretical ap-
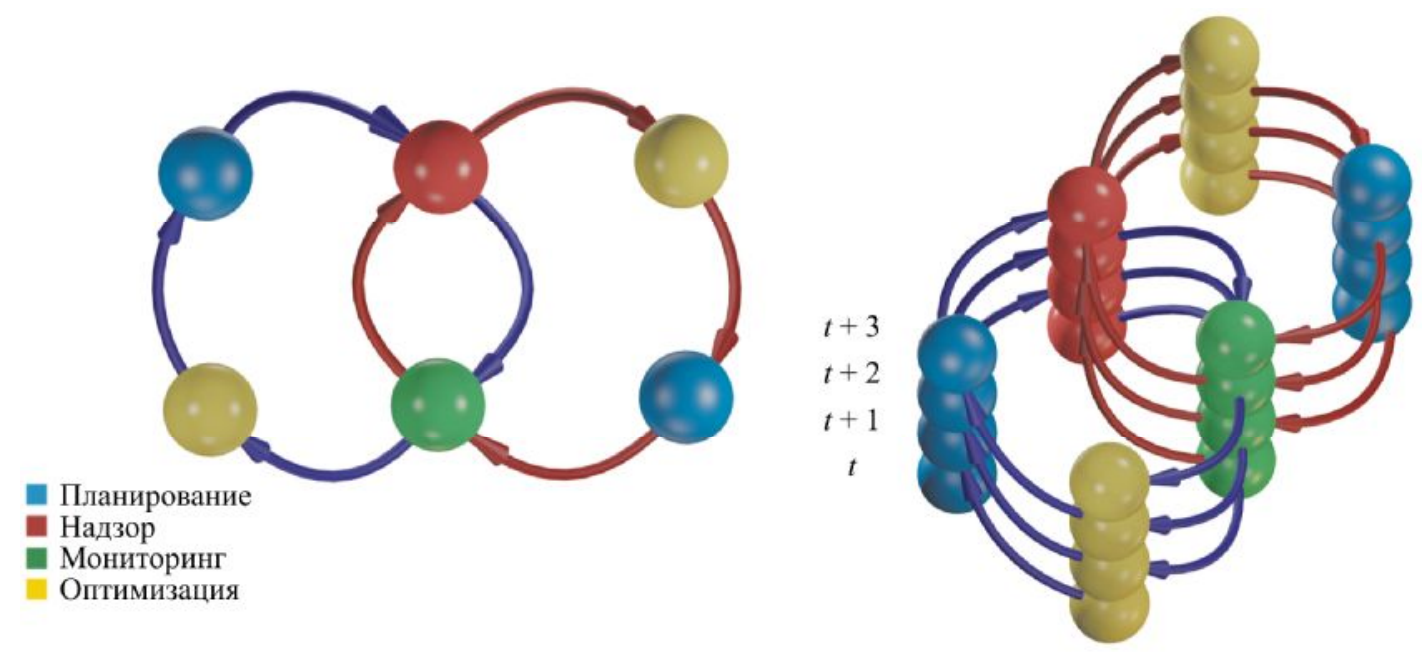

Figure 2. Three-dimensional image of interaction between managerial cycles for surveillance and control activities (blue arrows) and SHM system (red arrows). 
proaches to optimization of control and surveillance activities performed by Rospotrebnadzor on a regional level requires developing and implementing new techniques for complex planning; such planning should be based on interactions between Rospotrebnadzor subdivisions in the spheres of information exchange and systemic analysis of data taken from the departmental statistic reports and SHM regional information funds.

Necessary conditions for the systems integration are:

- keeping up a register of juridical persons and sole proprietors which are subjects to surveillance;

- calculating potential health risks which can be caused by each object under surveillance: it is necessary for objects ranking and surveillance activities plan$\operatorname{ning}^{3}$;

- spotting out objects which cause extremely high and high health risks for regional population;

- spatial binding of all such objects to territories;

- justifying "risk profiles" for objects under surveillance as a system of parameters which characterizes priority factors causing the overall risk level of an object and their internal relations;

- conjugating risk levels of an object with medical and demographic situation on a territory and spotting out territories with the highest mortality and morbidity shares associated with risks caused by an object under surveillance as a results of sanitary legislation being violated;
- creating SHM programs allowing for the following requirements: a monitoring point should be located on a territory where the highest potential health risk can be caused by an object under surveillance should sanitary legislation be violated and where the highest morbidity associated with a hazardous factor can occur; a monitoring program is aimed at measuring factors which cause the highest health risks; a monitoring program includes minimum sufficient number of observations which are required for the consequent analytical treatment.

Social and hygienic monitoring results should be taken into account in further planning and assessing efficiency of control and surveillance activities. Should social and hygienic monitoring results reveal there is environmental contamination which is dangerous for people's health, then the most essential task is to adjust control and surveillance activities concerning objects which can be a source of such contamination.

This approach fully corresponds to control and surveillance activities orientation at their ultimate result, namely, population health preservation. However, new tasks set stricter requirements to each element in social and hygienic monitoring and a risk-oriented model implemented into surveillance and control activities.

Stricter requirements are also set for the quality of registers which comprise economic entities being subject to sanitaryepidemiologic surveillance, as well as for correctness and transparency of calcula-

\footnotetext{
${ }^{4}$ On application of risk-oriented approach when organizing specific activities in the sphere of the state control (surveillance) and making alterations into some Orders by the RF Government (together with "The Rules for attributing activities performed by juridical persons and sole proprietors and (or) industrial objects used by them to a specific risk category or to a specific hazard category): The RF Governmental Regulations dated August 17, 2016 No. 806. Available at: http://docs.cntd.ru/document/420372694 (12.02.2018)
} 
tions related to an object ranking as per possible health risks.

There is a new task related to spotting out priority chemical, biological, and physical risk factors which are subject to measuring. Rospotrabnadzor's authorities and offices require a wider range of tools for situational modeling, including those based on GIS-platforms [14-16].

It is extremely vital to create a scientific-methodical foundation for accounting, evidencing, and registering cases in which damage was done to people's life or health as a result of sanitary legislation violation and when such violation was proved by SHM measuring results.

In accordance with item 4 , clause 8.3 of the 294-FL, all the control activities (inspections) which are performed without any interaction with juridical persons or sole proprietors should be accomplished basing on a set of inspection tasks approved by a surveillance authority supervisor. Given the above-mentioned, it is extremely essential to work out principles for drawing up such sets of tasks, their layout, and a form in which inspections results are to be presented.

Rospotrebnadzor authorities and offices have accumulated experience in conducting control inspections without any interaction with juridical persons or sole proprietors (in the spheres not related to sanitary surveillance). This experience proves that an inspection task should contain clear description of its goals, state its date, list all the basic information on an inspection object (its location, address, whom it belongs to and according to what rights). All the procedures are to be strictly documented. Inspection results are to be presented as an inspection report which should contain the following: a type of an inspection; information about a task this inspection was based on; a date or a period during which it took place; a time when it started and finished; its participants; a short descriptions of actions performed by an official and other participants; data obtained during it including the results of examinations, measuring, and observations; information on technical means which were applied for technical measuring; fixation of the inspection course and its results; data on any appendices to a report as well as explanations, additions or remarks made by inspection participants.

Schemes, tables, and measuring reports as well as any other supporting technical documents designed according to a established procedures are supplements to a report.

To sum up, a task to combine social and hygienic monitoring and surveillance and control activities is a vital one and requires the following:

- to work out and approve on a new edition of the regulations on SHM in relation to the Federal Law issued on June 29, 2016 No. 277- FL "On making alterations into the Federal Law «On protection of juridical persons and sole proprietors when the state and municipal control (surveillance) procedures are performed" and the Federal Law "On strategic planning in the Russian Federation";

- to develop a scientific approach to creating "risk profiles" for objects under sanitary-epidemiologic surveillance due to violation of sanitary-epidemiologic legislation;

- to give scientific grounds for selection of monitoring points and creation of programs for instrumental research on atmospheric air, natural and drinking water and soils in zones influenced by economic entities which cause extremely high, high, or significant health risks due to violation of obligatory requirements to environmental objects quality; 
- to create and document methodical approaches to specific research within SHM system which is control activities performed without interaction with juridical persons or sole proprietors in zones influenced by economic entities which cause extremely high, high, or significant health risks;

- to develop requirements to presentation of sampling and measuring results ob- tained during control inspections without interaction with juridical persons or sole proprietors and fix these requirements in regulatory documents;

- to work out scientific and organizational approaches to detecting, evidencing and registering cases in which damage was done to health due to violation of obligatory requirements by objects under sanitaryepidemiologic surveillance.

\section{References}

1. Popova A.Yu. Ctrategicheskie prioritety Rossiiskoi Federatsii v oblasti ekologii s pozitsii sokhraneniya zdorov'ya natsii [Strategic priorities of the Russian Federation in the field of ecology from the position of preservation of health of the nation]. Zdorov'e naseleniya $i$ sreda obitaniya, 2014, vol. 251, no. 2, pp. 4-7 (in Russian).

2. Nechukhaeva E.M., Maslov D.V., Afanas'eva S.I. Aktual'nye zadachi sotsial'nogigienicheskogo monitoringa na regional'nom urovne [Vital issues of social-hygienic monitoring at a regional level]. Zdorov'e. Meditsinskaya ekologiya. Nauka, 2010, vol. 41-42, no. 1-2, pp. 39-40 (in Russian).

3. Buzinov R.V., Unguryanu T.N., Lazareva N.K., Gudkov A.B. Organizatsiya sotsial'no gigienicheskogo monitoringa na territorii Arkhangel'skoi oblasti [Organization of socialhygienic monitorinin Arkhangelsk region]. Ekologiya cheloveka, 2006, no. 7, pp. 3-8 (in Russian).

4. Tsunina N.M., Zhernov Yu.V. Algoritm primeneniya rezul'tatov sotsial'nogigienicheskogo monitoringa na regional'nom urovne [The algorithm of application of results of social hygienic monitoring at regional level]. Problemy sotsial'noi gigieny, zdravookhraneniya $i$ istorii meditsiny, 2016, vol. 24, no. 2, pp. 77-81 (in Russian).

5. Kapranov S.V. Razrabotka sovremennoi sistemy monitoringa sredy zhiznedeyatel'nosti i sostoyaniya zdorov'ya naseleniya [Composition of the modern monitoring system of the environment of lifetime and status of population health]. Universitetskaya klinika, 2017, no. 4-2 (25), pp. 57-62 (in Russian).

6. Aidinov G.T., Marchenko B.I., Sofyanikova L.V., Sinel'nikova Yu.A. Primenenie mnogomernykh statisticheskikh metodov pri vypolnenii zadach sovershenstvovaniya informatsionno-analiticheskogo obespecheniya sistemy sotsial'no-gigienicheskogo monitoringa [The application of multidimensional statistical methods in the tasks of improving of information and analytical providing of the system socio-hygienic monitoring]. Zdorov'e naseleniya $i$ sreda obitaniya, 2015, no. 7, pp. 4-8 (in Russian).

7. Grozavu I.I., Kurbanbaeva D.F., Shmatko A.D. Napravleniya sovershenstvovaniya sotsial'nogigienicheskogo monitoringa [Trends in social-hygienic monitoring development]. NovaInfo. Ru, 2016, vol. 2, no. 54, pp. 307-311 (in Russian).

8. Zaitseva N.V., May I.V., Kleyn S.V. Optimizatsiya programm nablyudeniya za kachestvom atmosfernogo vozdukha selitebnykh territorii v sisteme sotsial'no-gigienicheskogo monitoringa na baze prostranstvennogo analiza i otsenki riska dlya zdorov'ya naseleniya [Optimization of programs for atmospheric air quality observations in the social-hygienic monitoring 
system based on spatial analysis and population health risk assessment]. Permskii meditsinskii zhurnal, 2010, vol. 27, no. 2, pp. 130-138 (in Russian).

9. Avaliani S.L., Novikov S.M., Shashina T.A., Dodina N.S., Kislitsin V.A., Mishina A.L. Problemy sovershenstvovaniya sistemy upravleniya kachestvom okruzhayushchei sredy na osnove analiza riska zdorov'yu naseleniya [The urgent problems of the improvement of the environment management system based on the analysis of health risk assessment]. Gigiena $i$ sanitariya, 2014, vol. 93, no. 6, pp. 5-8 (in Russian).

10. Better regulation in Europe: Executive summaries. OECD, 2010, 157 p. Available at: www.oecd.org/gov/regulatory-policy/45079126.pdf (02.02.2018).

11. Liou H.H., Oon P.C., Lin H.C., Wang P.J., Chen T.H. Risk factors associated with infantile spasms: a hospital-based case-control study in Taiwan. Epilepsy Research, 2001, vol. 47, no. 1-2, pp. 91-98.

12. Khan F.I., Sadiq R., Husain T. Risk-based process safety assessment and control measures design for offshore process facilities. Journal of Hazardous Materials, 2002, vol. 94, no. 1, pp. 1-36.

13. Eliovich I.G., Mel'tser A.V., Yakubova I.Sh., Alloyarov P.R., Istorik O.A., Pankina E.N., Zhirnov A.Yu. Sovershenstvovanie sotsial'no-gigienicheskogo monitoringa za usloviyami truda rabotnikov s ispol'zovaniem sistemy proizvodstvennogo kontrolya [Improvement of sociohygienic monitoring at worker's occupational conditions with the use of production control]. Gigiena i sanitariya, 2017, vol. 96, no. 4, pp. 339-343 (in Russian).

14. Kuz'min S.V., Gurvich V.B., Dikonskaya O.V., Nikonov B.I., Malykh O.L., Yarushin S.V., Kuz'mina E.A., Kochneva N.I., Kornilkov A.S. Sotsial'no-gigienicheskii monitoring i informatsionno-analiticheskie sistemy obespecheniya otsenki i upravleniya riskom dlya zdorov'ya naseleniya i risk-orientirovannoi modeli nadzornoi deyatel'nosti [Socio-hygienic monitoring and information analysis systems supporting the health risk assessment and management and a riskfocused model of supervisory activities in the sphere of securing sanitary and epidemiologic public welfare]. Gigiena i sanitariya, 2017, vol. 96, no. 12, pp. 1130-1136 (in Russian).

15. Kwak B.K., Kim J.H., Yi J., Park H.-S., Kim N.G., Choi K. A GIS-based national Emission inventory of major VOCS and risk assessment. Part II - Quantitative verification and risk assessment using an air dispersion model. Korean Journal of Chemical Engineering, 2010, vol. 27, no. 1, pp. 121-128.

16. Fushimi A., Kawashima H., Kajihara H. Source apportionment based on an atmospheric dispertion model and multiple linear regression analysis. Atmospheric Environment, 2005, vol. 39, no. 7, pp. 1323-1334.

Popova A.Yu., Zaitseva N.V., May I.V., Kiryanov D.A. Regulatory-legal and methodical aspects of social-hygienic monitoring and risk-oriented surveillance model integration. Health Risk Analysis, 2018, no. 1, pp. 4-12. DOI: 10.21668/health.risk/2018.1.01.eng

Received: 27.02 .2018

Accepted: 20.03.2018

Published: 30.03 .2018 